\title{
Comunicación
}

\section{Detección de Anticuerpos Contra el Virus de la Enfermedad de Aujeszky en Porcinos de Crianza Semi-tecnificada en Lima, Perú}

\author{
Detection of Antibodies Against Aujeszky ’s Disease Virus in Low Level \\ Management Pig Farms in Lima, Peru
}

\author{
Ana Castillo E. ${ }^{1}$, Hermelinda Rivera G. ${ }^{1,2}$, Mercy Ramírez V. ${ }^{1}$, \\ Alberto Manchego S. ${ }^{1}$
}

\section{Resumen}

El objetivo del presente estudio fue detectar anticuerpos contra el virus de la enfermedad de Aujeszky (EA) en porcinos de crianzas semi-tecnificadas de Lima Metropolitana. Se colectaron 463 muestras de sangre de cerdos sin distinción de sexo y mayormente entre 130 a 150 días de edad, aparentemente normales, en un centro de beneficio de Lima, Perú. Los cerdos procedían de 13 distritos de Lima Metropolitana y la detección de los anticuerpos neutralizantes contra el virus de la EA fue mediante la prueba de neutralización viral. Todas las muestras resultaron negativas a anticuerpos contra el virus de la EA.

Palabras clave: porcino, crianza semi-tecnificada, virus de la enfermedad de Aujeszky, anticuerpos, neutralización viral

\section{Abstract}

The aim of this study was to detect antibodies against the virus of Aujeszky's disease (ADV) in low level management pig farms in Lima, Peru. Blood samples were collected $(n=463)$ from apparently healthy pigs, regardless of sex and mostly between 130

\footnotetext{
${ }^{1}$ Laboratorio de Microbiología y Parasitología Veterinaria, Facultad de Medicina Veterinaria, Universidad Nacional Mayor de San Marcos, Lima, Perú

${ }^{2}$ E-mail: hriverag2014@yahoo.es
} 
to 150 days old. The animals were from 13 districts of Metropolitan Lima. Neutralizing antibodies against ADV were analysed by the virus neutralization test. All samples resulted negative to antibodies against ADV.

Key words: swine, poor managed pig farms, Aujeszky’s disease virus, antibodies, virus neutralization

\section{INTRODUCCIÓN}

La población porcina en el Perú es de 2224 300, es decir, 1.7\% más que la población registrada en el censo agropecuario de 1994. De esta población, el $67.2 \%$ son cerdos criollos, mayormente criados en la sierra y selva bajo crianza familiar y el $32.8 \%$ restante son cerdos de razas definidas presentes en la costa bajo crianza tecnificada (MINAGRI, 2006; INEI, 2012).

En la última década el Sub-Sector Pecuario ha alcanzado un gran desarrollo, con una tasa de incremento anual $2.04 \%$ (producción porcina en 2.4\%) (INEI, 2014). No obstante, las enfermedades infecciosas constituyen serias amenazas a la producción y reproducción porcina. Las enfermedades emergentes y aquellas que causan pérdidas no solo como enfermedad, sino también por ser restrictivas para el comercio internacional, como la enfermedad de Aujeszky, tienen gran impacto económico.

La enfermedad de Aujeszky (EA) o pseudorrabia es producida por el virus de la Enfermedad de Aujeszky, miembro de la familia Herpesviridae, subfamilia alfaherpesvirinae (Mayo y Pringle, 1998). El virus afecta al porcino y otras especies de animales, afectando el sistema nervioso, sobre todo en lechones, además del aparato respiratorio y reproductivo (Muller et al., 2011). El cerdo es el reservorio del virus, donde persiste en los ganglios neuronales, dificultado su erradicación de granjas porcinas infectadas (Pomeranz et al., 2005).
En el país no existe información documentada de la presencia de casos clínicos de la EA; sin embargo, anticuerpos y antígenos del virus han sido detectados en porcinos de crianza no tecnificada (Manchego et al., 1998). En un reciente estudio serológico realizado en porcinos a nivel nacional para la detección de anticuerpos contra el virus de la EA se encontraron siete $(0.4 \%)$ animales seropositivos y estos estaban presentes en los departamentos de Pasco y Piura (K. Portilla, SENASA-Lima, comunicación personal).

La costa del departamento de Lima es una de las zonas de mayor desarrollo de la industria porcina, aunque en muchas granjas los cerdos son criados con escasa tecnología y sin bioseguridad, de allí que podrían ser reservorios de enfermedades como Aujeszky y constituir un riesgo para las granjas porcinas tecnificadas. Ante la ausencia de datos actualizados sobre la presencia de la EA en animales de crianza semi-tecnificada de Lima, se realizó el presente estudio con el objetivo de determinar la frecuencia de cerdos con anticuerpos contra el virus de la EA en parques porcinos de Lima.

\section{Materiales y Métodod}

En base a un muestreo no probabilístico se obtuvieron muestras de sangre de 463 cerdos, entre machos y hembras, mayormente de 130 a 150 días de edad, durante el beneficio en un camal de Lima. Los cerdos estaban en aparente buen estado de salud y procedían de criaderos semi-tecnificados de los 
Cuadro 1. Procedencia y número de muestras de suero de porcino obtenidos por distrito

\begin{tabular}{llcc}
\hline Zona de Lima & Distrito & $\begin{array}{c}\text { Muestras por } \\
\text { distrito } \\
(\mathrm{n})\end{array}$ & $\begin{array}{c}\text { Muestras por } \\
\text { zona } \\
(\mathrm{n})\end{array}$ \\
\hline Norte & Carabayllo & 14 & 55 \\
& Ventanilla & 41 & 280 \\
& San Juan de Miraflores & 27 & \\
& Pamplona & 48 & \\
& Lurín & 41 & 128 \\
& San Bartolo & 14 & \\
& Villa El Salvador & 100 & \\
& Villa María del Triunfo & 31 & \\
& Chorrillos & 19 & 463 \\
& San Juan de Lurigancho & 34 & \\
& Huachipa & 59 & \\
\hline Total & Chosica & 16 & \\
& La Molina & 19 & \\
\hline
\end{tabular}

parques porcinos ubicados en 13 distritos de la ciudad de Lima (Cuadro 1). Las muestras fueron transportadas de inmediato al Laboratorio de Virología de la Facultad de Medicina Veterinaria (FMV), Universidad Nacional Mayor de San Marcos (UNMSM), Lima, para la obtención del suero mediante centrifugación a $800 \mathrm{~g}$ por 5 min y conservadas en viales a $-20{ }^{\circ} \mathrm{C}$.

Los anticuerpos contra el virus de la EA fueron detectados mediante la prueba de neutralización viral según lo establecido en el Manual de Pruebas Diagnósticas y Vacunas para Animales Terrestres (OIE, 2012) utilizando la cepa Shoop del virus de EA con un título de $10^{-6} \mathrm{DI}_{50} / 50 \mu \mathrm{l}$, sueros positivos controles y células secundarias de cornete nasal bovino como un sistema indicador de la neutralización viral. Una muestra de suero fue considerada positiva a anticuerpos cuando fue capaz de neutralizar el $100 \%$ de la capacidad infectante del virus en la monocapa de CNB y fue considerada negativa a anticuerpos cuando se observó el $100 \%$ del efecto citopático en la monocapa de CNB.

\section{Resultados y Discusión}

Todas las muestras resultaron negativas a anticuerpos neutralizantes contra el virus de la EA. El virus de la EA como todos los virus herpes, luego de una infección primaria puede permanecer en estado de latencia en neuronas del ganglio trigémino y tejidos linfoides del animal de donde puede reactivarse de tiempo en tiempo induciendo una infección intermitente aguda o subclínica seguida por una respuesta por anticuerpos en títulos variables contra el virus (Perng et al., 2000); por tanto, la ausencia de anticuerpos indica que el virus no estuvo presente en los porcinos muestreados.

La edad de los animales en estudio podría haber afectado los resultados en caso el virus se encontrase presente, pues es más común encontrarlo en marranas y reproductores adultos (Morilla et al., 1995, 1996). En un estudio realizado en marranas adultas provenientes de crianza de traspatio 
de Lima se detectó antígeno del virus de la EA en tonsilas, nódulos linfáticos y bazo en el $6.5 \%$ (12/185) de los animales, mientras que en el parque porcino de Ventanilla el virus fue detectado en el 15.5\% (17/110) de marranas con problemas neumónicos (Rivera et al., trabajos no publicados). Sin embargo, en el presente estudio las muestras de suero provenientes de porcinos de Ventanilla fueron negativas a anticuerpos, incluidas dos marranas adultas.

Los animales seropositivos a la EA detectados en el país han sido animales adultos sin signos clínicos de la EA y únicamente en cerdos de crianza familiar y de crianza semitecnificada, a diferencia de algunos casos ocurridos en países como Bolivia donde la EA afectó a lechones de granjas porcinas de crianza intensiva, con alto porcentaje de mortalidad en las provincias del Chaco y Chuquisaca en el 2005 (OIE, 2006).

Las pruebas disponibles para la detección de anticuerpos contra el virus de la EA son ELISA, aglutinación en látex y neutralización viral (NV), siendo esta última considerada como la prueba estándar. La prueba de ELISA es más utilizada por su facilidad y permite procesar numerosas muestras comparado con la prueba de NV, además de presentar una especificidad y sensibilidad de más de 90\% (Boadella et al., 2012). En cambio, la sensibilidad de la prueba de NV es menor, dependiendo de las células utilizadas como sistema indicador (Kinker et al., 1997; OIE, 2012). La técnica de PCR es una herramienta de alta sensibilidad que podría ser utilizada para detectar el ADN del virus de la EA en estado de latencia en el tejido nervioso de porcinos adultos (McCaw et al., 1997; Yoon et al., 2005).

El resultado del presente estudio no descarta totalmente la posibilidad de que el virus de la EA existe en los animales adultos de crianza semi-tecnificada.

\section{Agradecimiento}

Los autores agradecen a las bachilleres en Medicina Veterinaria Diana Benito F. y María Alejandra Aranda H. por su valioso apoyo en la colección de las muestras de sangre. El trabajo fue parcialmente financiado por el Consejo Superior de Investigaciones de la Universidad Nacional Mayor de San Marcos (Proyecto N. ${ }^{\circ}$ 140801121).

\section{Literatura Citada}

1. Boadella M, Gortázar C, Vicente J, Ruiz-Fons F. 2012. Wild boar: an increasing concern for Aujeszky's disease control in pigs? BMC Vet Res 8(1): 7. doi: 10.1186/1746-6148-8-7

2. [INEI] Instituto Nacional de Estadística e Informática. 2012. IV Censo Nacional Agropecuario. [Internet]. Disponible en: http://www.inei.gob.pe/

3. [INEI] Instituto Nacional de Estadística e Informática. 2014. Producción nacional. Informe Técnico $\mathrm{N}^{\circ} 3$ marzo 2014. 37 p. [Internet]. Disponible en: http:/ / w w w. inei.gob.pe/media/ MenuRecursivo/boletines/01produccion-nacional-noviembre2013_1.pdf

4. Kinker DR, Swenson SL, Wu LL, Zimmerman JJ. 1997. Evaluation of serological tests for the detection of pseudorabies $\mathrm{gE}$ antibodies during early infection. Vet Microbiol 55: 99-106.

5. Manchego A, Cerón M, Salas A, Gonzales A, Sandoval N, Rivera H, Rosadio R. 1998. Evidencia serológica del virus de la enfermedad de Aujeszky (pseudorrabia) en porcinos. Rev Inv Pec 9(1): 38-43.

6. Mayo MA, Pringle CR. 1998. Virus taxonomy - 1997. J Gen Virol 79: 649657 
7. McCaw MB, Osorio FA, Wheeler J, Xu J, Erickson GA. 1997. Effect of maternally acquired Aujeszky's disease (pseudorabies) virus-specific antibody in pigs on establishment of latency and seroconversion to differential glycoproteins after low dose challenge. Vet Microbiol 55: 91-98.

8. [MINAGRI] Ministerio de Agricultura y Riego. 2006. Porcinos. Situación actual. [Internet]. Disponible en: http:// www.minag.gob.pe/portal/sector-agrario/ pecuaria/organizaciones-de-productores

9. Morilla AG. 1996. Control y erradicación de la enfermedad de Aujeszky. Ciencia Vet 7: 241-271.

10. Morilla A, Diosdado F, Corona E, Soria S, González-Vega D. 1995. Perfiles serológicos de granjas porcinas infectadas con el virus de la enfermedad de Aujeszky. Tec Pec Mex 33: 92-99.

11. Müller T, Hahn EC, Tottewitz F, Kramer M, Klupp BG, Mettenleiter TC, Freuling C. 2011. Pseudorabies virus in wild swine: a global perspective. Arch Virol 156: 1691-1705. doi: 10.1007/ s00705-011.1080-2

12. [OIE] Organización mundial de salud animal. 2006. Enfermedad de Aujeszky en Bolivia Sanitarias 19 (21):
407-424. [Internet]. Disponible en: http:/ /web.oie.int/esp/info/hebdo/EIS_17.htm

13. [OIE] Organización Mundial de Sanidad Animal. 2012. Manual de las pruebas de diagnóstico y de las vacunas para los animales terrestres. Chapter 2.1.2. Aujeszky's Disease. 15 p. [Internet]. Disponible en: http:// www.oie.int/fileadmin/Home/eng/ $\mathrm{Health}$ _ s tandard s/ta h m / 2.01.02_aujeszkys_dis.pdf

14. Perng GC, Jones CJ, Ciacci-Zanella J, Stone M, Henderson GA, Yukht A, Slanina SM, et al. 2000. Virus-induced neuronal apoptosis blocked by the herpes simplex virus latency-associated transcript. Vet Bio Sci 287: 1500-1503. doi: 10.1126/science.287.5457.1500

15. Pomeranz LE, Yeynolds AE, Hengartner CJ. 2005. Molecular biology of pseudorabies virus: impact on neuroviology and veterinary medicine. Microbiol Mol Biol Rev 69: 462-500. doi: 10.1128/MMBR.69.3.462-500.2005

16. Yoon HA, Eo SK, Aleyas AG Park SO, Lee JH, Chae JS, Cho JG Song HJ. 2005. Molecular survey of latent pseudorabies virus infection in nervous tissues of slaughtered pigs by nested and real time PCR. J Microbiol 43: 430-436. 